\title{
The first checklist of macrofungi of mount Cameroon
}

\author{
Kinge $\mathrm{TR}^{1 *}$, Egbe $\mathrm{EA}^{2}$, Tabi $\mathrm{EM}^{2}, \mathrm{Nji} \mathbf{T M}^{3}$ and $M i h \mathrm{AM}^{2}$ \\ ${ }^{1}$ Department of Biological Sciences, Faculty of Science, University of Bamenda, P.O. Box 39, North West Region, \\ Cameroon. \\ ${ }^{2}$ Department of Botany and Plant Physiology, Faculty of Science, University of Buea, P.O. Box 63,South West Region, \\ Cameroon \\ ${ }^{3}$ Department of Sociology and Anthropology, Faculty of Social and Management Sciences, University of Buea, P.O. \\ Box 63, South West Region, Cameroon
}

Kinge TR, Egbe EA, Tabi EM, Nji TM, Mih AM 2013 - The first checklists of macrofungi of mount Cameroon. Mycosphere 4(4), 694-699, Doi 10.5943/mycosphere/4/4/5

\begin{abstract}
Field studies were carried out in the Mount Cameroon Region, Cameroon between 2010 and 2012. A total of 520 samples of macrofungi were collected. As a result of field and laboratory studies, a checklist of 177 species of fungi belonging to 83 genera is presented. The Basidiomycetes had 163 species, while the Ascomycetes had 14 species. All the species identified are new records for the area.
\end{abstract}

Key Words - Cameroon - mushrooms - mycoflora - taxonomy

\section{Introduction}

The Mount Cameroon Region is situated in the South West Region of Cameroon in Central Africa. The area extends from the Atlantic coast to the enormous Mount Cameroon, with an altitude of $4100 \mathrm{~m}$ (Bussmann 2006). Mount Cameroon is the highest mountain in West and Central Africa with an active volcano. The last two eruptions were recorded in 1999 and 2000. It is located between latitudes $3^{\circ} 57^{\prime}$ to $4^{\circ} 27^{\prime} \mathrm{N}$ and longitudes $8^{\circ} 58^{\prime}$ to $9^{\circ} 24^{\prime} \mathrm{E}$ (Suh et al. 2003). The peak is at $4^{\circ} 7^{\prime} \mathrm{N}$ and $9^{\circ} 10^{\prime} \mathrm{E}$ (Tchouto 1996). Due to the volcanic origin, the surrounding soil is rich in nutrients and provides high fertility for both natural vegetation and farmland (Fonge et al. 2005). The area has a humid tropical climate and the climatic pattern is modified by the topography from sea level to the top of the mountain. The annual rainfall on the mountain varies between 2085 and $10,000 \mathrm{~mm}$. The mean annual temperature is about $25^{\circ} \mathrm{C}$, and this decreases by $0.6^{\circ} \mathrm{C}$ per $100 \mathrm{~m}$ ascent (Fraser et al. 1998). The climate of the Mount Cameroon region is predominantly tropical, showing a definite rainy/dry season, with very high rainfall and high temperatures along the coastal belt. Rainfall and temperatures diminish and are moderated up the slopes and further inland. The indigenous inhabitants of the mountain belong to the Bakweri tribe.

The study of mycoflora in Cameroon can be divided into three periods: 1) the pioneer phase during which Bresadola and Hennings studied fungi from the southern and atlantic coast of Cameroon; 2) the period during European settlement when Hein, Berthet and Boidin studied fungi from the west, south and center regions of Cameroon; and 3) the postcolonial period during which 
Colonge and Daniels, and Nunez and Daniels studied fungi from the Dja Biosphere Reserve, Watling, Hjortstam and Roberts studied fungi from the Korup National Park, Mosseebo and Antonin studied Marasmus species collected in the vicinity of Yaounde, in stands under human impacts and Douanla-Meli studied fungi from the Mbalmayo forest reserve in Cameroon (DouanlaMeli 2007). According to the relevant literature available to us, no studies on macrofungal flora have been carried out in the Mount Cameroon Region, even though the plants of Mount Cameroon have been extensively studied and documented (Cable \& Cheek 1998). The purpose of this paper is to prepare the first check list of macrofungi of the Mount Cameroon Region.

\section{Materials \& Methods}

Specimens of macrofungi were collected during field trips (2010-2012) carried out on four flanks of Mount Cameroon Region: the windward side (Idenau), the leeward side (Ekona Lelu), the midward side (Buea Town) and the hind side of the mountain (Bafia) (Fig. 1). Collecting sites included undisturbed forest, secondary forests, cocoa farms, palm plantations, food crop fields, bush fallow and farmers' trails.

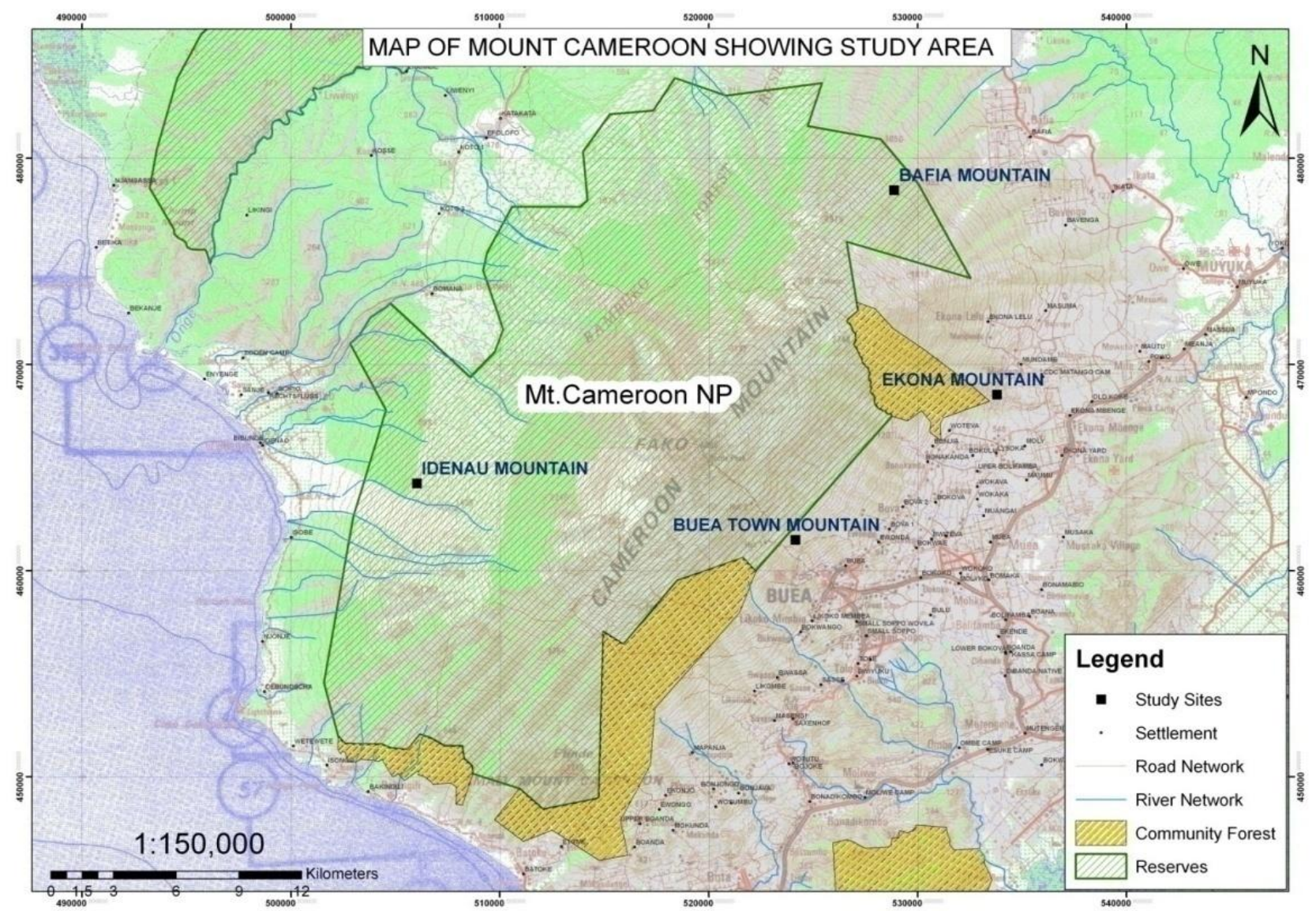

Fig. 1 - Study sites for diversity and distribution studies of macrofungi in the Mount Cameroon Region.

The ecological and morphological characteristics of the fruiting bodies were recorded and they were photographed in their natural habitats. They were taken to the laboratory, dried and preserved in polyethylene bags containing silica gel crystals. As a result of macroscopic and microscopic investigations, they were identified with the help of Douanla-Meli (2007). The samples are kept in the University of Buea education facility. 


\section{Results and Discussion}

A total of 177 species in 83 genera were collected (Table 1). There were 163 species of Basidiomycetes and 14 species of Ascomycetes. The identified species belonged to 38 families of 15 orders. A majority of the fungi belonged to the Agaricales (87 species), followed by the Polyporales (32 species) while the Eurotiales, Nidulariales and Phallales were each represented by a single species. The most abundant family was the Polyporaceae with 21 species, followed by Marasmiaceae and Tricholomataceae represented by 18 and 17 species, respectively. Some of the mushroom species identified were used as food and in ethnomedicine (Kinge et al. 2011).

The heavy rainfall and high humidity in the region might have favoured the high number of macrofungi recorded. This study is the first documentation of macrofungi in the Mount Cameroon Region. Future investigations will certainly increase the number of fungal records and expand the reported species ranges throughout the area.

Table 1 Checklists of macrofungi in Mount Cameroon Region

\begin{tabular}{|c|c|}
\hline Species & Location \\
\hline Coprinus micaceus & Idenau, Bafia \\
\hline Coprinus plicatilis & Ekona \\
\hline Coprinus sp. & Bafia \\
\hline Crepidotus mollis & Bueatown \\
\hline Crepidotus subsphaerosporus & Bueatown \\
\hline Cyathus striatus & Bueatown \\
\hline Daedaleopsis confragosa & Idenau, Bafia, Ekona \\
\hline Daldinia concentric & Bafia, Bueatown, Ekona \\
\hline Dictyophora indusiata & Idenau, Bueatown, Bafia \\
\hline Echinochaete sp. & Bueatown \\
\hline Entoloma sp. & Bueatown \\
\hline Flammulina velutipes & Bafia \\
\hline Flavolus brasiliensis & Idenau, Bafia \\
\hline Ganoderma applanatum & Ekona, Bueatown, Idenau \\
\hline Ganoderma lucidum & Bafia, Bueatown \\
\hline Ganoderma ryvardenii & Idenau, Bueatown, Ekona \\
\hline Ganoderma zonatum & Idenau \\
\hline Ganoderma sp. & Bafia, Ekona \\
\hline Geastrum mirabile & Bafia, Bueatown \\
\hline Geastrum saccatum & Ekona, Bueatown \\
\hline Geastrum triplex & Ekona \\
\hline Gerronema beninensis & Idenau \\
\hline Guepinia spathularia & Bueatown \\
\hline Haploporus odorus & Bueatown \\
\hline Hygrocybe sp. & Ekona, Bueatown \\
\hline Hygrophorus sp. & Bueatown, Idenau \\
\hline Hypholoma marginatum & Ekona \\
\hline Inonotus radiates & Bafia, Idenau, Ekona \\
\hline Laccaria amethystine & Bafia \\
\hline Laccaria laccata & Idenau \\
\hline Lactarius intermedius & Bueatown \\
\hline Lentinus sajor-caju & Idenau \\
\hline Lentinus sp. & Bafia \\
\hline Lentinus tigrinus & Idenau \\
\hline Lenzites acuta & Bafia \\
\hline Lenzites betulina & Bafia, Ekona, idenau \\
\hline Lenzites sp. & Idenau, Ekona \\
\hline Lenzites warnieri & Ekona \\
\hline Lepiota cristata & Bafia, Bueatown \\
\hline Lepista sp. & Ekona \\
\hline
\end{tabular}




\begin{tabular}{|c|c|}
\hline Species & Location \\
\hline Lycoperdon pyriforme & Idenau \\
\hline Lyophyllum sp. & Bueatown \\
\hline Macrolepiota rhacodes & Bafia \\
\hline Marasmiellus chamaecyparidis & Bafia, Ekona \\
\hline Marasmiellus ramealis & Idenau \\
\hline Marasmiellus vaillantii & Idenau \\
\hline Marasmius candidus & Ekona \\
\hline Marasmius cohaerens & Ekona \\
\hline Marasmius graminum & Ekona \\
\hline Marasmius maximus & Bueatown, Ekona \\
\hline Marasmius ohshimae & Ekona \\
\hline Marasmius oreades & Ekona, Bafia \\
\hline Marasmius pulcherripes & Bafia, Ekona \\
\hline Marasmius pura & Idenau \\
\hline Marasmius purpureostriatus & Bafia \\
\hline Marasmius rotula & Bafia \\
\hline Marasmius scorodonius & Bafia \\
\hline Marasmius siccus & Bafia, Idenau \\
\hline Marasmius undatus & Ekona, Bowntown \\
\hline Micromphale sp. & Ekona \\
\hline Microporus affinis & Bueatown \\
\hline Mycena galopus & Bafia \\
\hline Mycena haematopus & Ekona \\
\hline Mycena pura & Ekona, Bueatown \\
\hline Mycena rhenana & Idenau \\
\hline Mycena stipata & Ekona, Bueatown \\
\hline Mycena tenerrima & Ekona, Bafia \\
\hline Nigroporus vinosus & Bueatown, Bafia \\
\hline Nothopanus hygrophanus & Bueatoiawn \\
\hline Oudemansiella canarii & Bafia, EkoBafiana, Bueatown \\
\hline Oudemansiella radicata & Idenau \\
\hline Oudemansiella sp & Ekona \\
\hline Oxyporus corticola & Idenau, Ekona \\
\hline Panellus stipiticus & Bueatown \\
\hline Panus fulvus & Ekona \\
\hline Panus sp. & Bafia \\
\hline Penicilliopsis sp. & Bafia \\
\hline Perenniporia ochroleuca & Idenau, Bueatown \\
\hline Pezziza badida & Ekona \\
\hline Pezziza sp. & Bafia \\
\hline Phellinus gilvus & Bueatown \\
\hline Phellinus igniarius & Bueatown \\
\hline Phellinus noxius & Idenau, Ekona \\
\hline Phellinus sp. & Ekona \\
\hline Phellinus xeranticus & Idenau, Bueatown, Bafia \\
\hline Phillipsia domingensis & Bafia, Bueatown \\
\hline Pholiota highlandensis & Bueatown \\
\hline Phylloporus tenuipes & Idenau \\
\hline Plectania nannfeldtii & Ekona \\
\hline Pleurotus flabellatus & Idenau, Ekona \\
\hline Pleurotus luteoalbus & Bueatown, Bafia, Ekona \\
\hline Pleurotus pulmonarius & Bueatown \\
\hline Pleurotus squarrosulus & Idenau, Bafia \\
\hline Pleurotus tuberregium & Bueatown \\
\hline Polyporus tenuiculus & Bueatown \\
\hline Psathyrella sp. & Bueatown \\
\hline Psathyrella spadiceogrisea & Bueatown \\
\hline Pycnoporellus fulgens & Idenau \\
\hline Ramaria fennica & Bueatown \\
\hline Ramaria ochraceovirens & Bueatown \\
\hline
\end{tabular}




\begin{tabular}{|c|c|}
\hline Species & Location \\
\hline Ramaria pallid & Idenau, Bueatown \\
\hline Rigidoporus lineatus & Idenau \\
\hline Rigidoporus microporus & Idenau, Bafia, Ekona \\
\hline Russula acriannulata & Ekona \\
\hline Russula anthracina & Bafia, Ekona \\
\hline Russula cosobrina & Bueatown \\
\hline Russula earlei & Idenau \\
\hline Russula emetic & Bueatown \\
\hline Russula gracillima & Bueatown \\
\hline Russula luteotacta & Bueatown \\
\hline Schizophyllum commune & Bafia \\
\hline Scleroderma $\mathrm{sp}$ & Idenau \\
\hline Scutellinia stecullata & Bafia, Idenau, Bueatown \\
\hline Termitomyces medius & Bafia \\
\hline Termitomyces sp. & Bafia \\
\hline Trametes cervina & Bafia \\
\hline Trametes elegans & Idenau, Bafia, Ekona \\
\hline Trametes pubescens & Bueatown \\
\hline Trametes sp. & Bafia \\
\hline Trametes versicolor & Bafia, Ekona, Idenau, Bueatown \\
\hline Tremella fuciformis & Bafia, Ekona \\
\hline Tremella mesenterica & Ekona \\
\hline Tremella sp. & Idenau \\
\hline Tricholoma sp. & Bueatown \\
\hline Tricholoma ustale & Idenau \\
\hline Vascellum pretense & Bafia \\
\hline Volvariella volvacea & Idenau, Bafia \\
\hline Xeromphalina tenuipes & Idenau \\
\hline Xylaria carpophila & Idenau, Bafia, Ekona, Bueatown \\
\hline Xylaria hypoxylon & Idenau, Bafia \\
\hline Xylaria polymorpha & Idenau, Bafia, Bueatown \\
\hline Xylaria sp. & Idenau, Bueatown \\
\hline Xylaria tuberoides & Ekona \\
\hline
\end{tabular}

\section{Acknowledgements}

This research was funded by the Rufford small grant for nature conservation awarded to the first author. We thank all the field guides and village heads of the different local communities for assistance during field collection.

\section{References}

Bussmann RW. 2006 - Vegetation zonation and nomenclature of African Mountains - an overview. Lyonia 11, 41-66.

Cable S, Cheek M. 1998 -The Plants of Mount Cameroon: A Conservation Checklist. Royal Botanic Gardens Kew, 279pp.

Douanla-Meli C. 2007- Fungi of Cameroon: ecological diversity with emphasis on the taxonomy of non-gilled Hymenomycetes from the Mbalmayo Forest Reserves. Bibliotheca Mycologica, 410pp

Fonge BA, Yinda GS, Focho DA, Fongod AGN, Bussmann RW. 2005 - Vegetation and soil status on an 80-year-old lava flow of Mt. Cameroon, West Africa. Lyonia 8, 17-39.

Fraser PJ, Hall JB, Healey JR. 1998 - Climate of the Mount Cameroon Region, long and medium term rainfall, temperature and sunshine data. 56p, (unpl), SAFS, University of Wales Bangor, MCP-LBG, Limbe.

Kinge TR, Tabi EM, Mih AM, Egbe EA, Njouonkou LA, Nji, TM. 2011 -Ethnomycology studies of macro-fungi (mushrooms) in the Mount Cameroon Region. International Journal of Medicinal Mushroom 13, 299-305. 
Suh CE, Sparks RSJ, Fitton, JG, Ayonghe SN, Annen C, Nana R, Luckman A. 2003 - The 1999 and 2000 eruptions of Mt. Cameroon; eruption, behaviour and petrochemistry of lava. Bulletin of Volcanicity 65, 267-281.

Tchouto P. 1996 - Forest Inventory Report of the proposed Etinde Rainforest Reserve. Mount Cameroon Project, S. W. P. Cameroon. 